\title{
Scabies crustosa in a recipient of an allogeneic stem cell transplantation
}

\author{
Maximilian Christopeit ${ }^{1} \cdot$ Dominic Wichmann ${ }^{2}$
}

Received: 25 February 2020 / Accepted: 2 April 2020 / Published online: 8 April 2020

(c) The Author(s) 2020

A 49-year-old woman presented with crustuous efflorescences covering $\approx 70 \%$ of an erythematous skin (Fig. 1). She developed hypotension and a partially compensated metabolic acidosis ( $\mathrm{pH}: 7.16 ; \mathrm{CO}_{2}: 32 \mathrm{mmHg}$ ).

Allogeneic hematopoietic stem cell transplantation from a matched unrelated donor following myeloablative conditioning including anti-T-lymphocyteglobulin had been performed 2 months prior to treat relapsed stage IVB Hodgkin's lymphoma. A localized scabies infection occurring at the end of the aplastic phase was treated with ivermectin in the recommended dose of $200 \mu \mathrm{g} / \mathrm{kg}$ bodyweight on days 1 and 8 , each. After transplantation, visits to the outpatient unit frequently deviated from schedule, clinical status was poor, and cyclosporine levels were below target level.

Scabies crustosa, historically referred to as scabies norvegica, and septic shock were diagnosed. Despite fluid and vasopressor resuscitation, antimicrobial, anti-parasitic and anti-inflammatory drug treatment, continuous renal replacement therapy, and respiratory support, she died due to multi-organ failure 1 day after initial presentation. Blood cultures taken the day before grew Enterococcus faecium.

Scabies is a parasitic disease caused by the mite Sarcoptes scabiei var. hominis [1]. In Western Europe, scabies can be of concern in communities with social problems, and in patients with risk factors such as promiscuity and advanced age. Due to defective T cell responses, immunosuppressed patients are at increased risk of experiencing crusted scabies, previously referred to as scabies norvegica $[2,3]$. Production of complement inhibitors by the mites results in an increased risk for secondary infections caused by streptococci and staphylococci in the affected patients [4]. Treatment options for scabies are systemic oral ivermectin (USA: FDA off-label, EU: EMA approved), or topical permethrin [5].
Maximilian Christopeit

mchristo@uke.de

$\triangle$ Dominic Wichmann

d.wichmann@uke.de

1 Department of Stem Cell Transplantation, University Medical Center Hamburg-Eppendorf, Martinistrasse 52, 20246 Hamburg, Germany

2 Department of Intensive Care Medicine, University Medical Center Hamburg-Eppendorf, Martinistrasse 52, 20246 Hamburg, Germany 


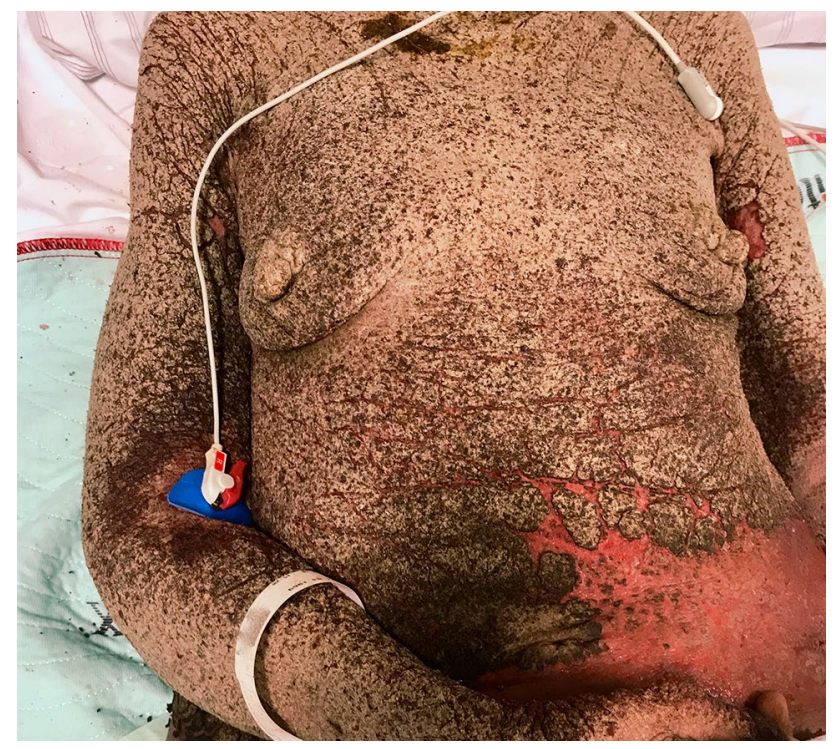

Fig. 1 A 49-year-old female patient after allogeneic hematopoietic stem cell transplantation for Hodgkin's lymphoma with classical signs of crusted scabies

Acknowledgements Open Access funding provided by Projekt DEAL.

\section{Compliance with ethical standards}

Conflict of interest MC and DW declare no conflict of interest with regards to this report. No financial support was granted for the preparation of this work.
Open Access This article is licensed under a Creative Commons Attribution 4.0 International License, which permits use, sharing, adaptation, distribution and reproduction in any medium or format, as long as you give appropriate credit to the original author(s) and the source, provide a link to the Creative Commons licence, and indicate if changes were made. The images or other third party material in this article are included in the article's Creative Commons licence, unless indicated otherwise in a credit line to the material. If material is not included in the article's Creative Commons licence and your intended use is not permitted by statutory regulation or exceeds the permitted use, you will need to obtain permission directly from the copyright holder. To view a copy of this licence, visit http://creativecommons.org/licenses/by/4.0/.

\section{References}

1. Markova A, Kam SA, Miller DD, Lichtman MK. In the clinic. Common cutaneous parasites. Ann Intern Med. 2014;161(5):ITC1.

2. Chosidow O. Clinical practices. Scabies N Engl J Med. 2006;354(16):1718-27.

3. Del Borgo C, Belvisi V, Tieghi T, Mastroianni CM. Atypical presentation of crusted (Norwegian) scabies. Infection. 2015;43(5):623-4.

4. Swe PM, Christian LD, Lu HC, Sriprakash KS, Fischer K. Complement inhibition by Sarcoptes scabiei protects Streptococcus pyogenes - an in vitro study to unravel the molecular mechanisms behind the poorly understood predilection of $S$. pyogenes to infect mite-induced skin lesions. PLoS Negl Trop Dis. 2017;11(3):e0005437.

5. Romani L, Whitfeld MJ, Koroivueta J, Kama M, Wand H, Tikoduadua L, et al. Mass drug administration for scabies control in a population with endemic disease. N Engl J Med. 2015;373(24):2305-13. 